\title{
Analysis of Genetic Diversity of Fusarium tupiense, the Main Causal Agent of Mango Malformation Disease in Southern Spain
}

\author{
M. Crespo, F. M. Cazorla, and A. de Vicente, Instituto de Hortofruticultura Subtropical y Mediterránea "La Mayora", Universidad de Málaga, \\ Consejo Superior de Investigaciones Científicas, Departamento de Microbiología, Facultad de Ciencias, Campus de Teatinos s/n, 29071, \\ Málaga, Spain; E. Arrebola and J. A. Torés, Instituto de Hortofruticultura Subtropical y Mediterránea "La Mayora", Universidad de Málaga, \\ Consejo Superior de Investigaciones Científicas, Estación Experimental La Mayora, Algarrobo-Costa, 29750, Málaga, Spain; M. Maymon and \\ S. Freeman, Department of Plant Pathology and Weed Research, Agricultural Research Organization (ARO), The Volcani Center; Bet Dagan \\ 50250, Israel; T. Aoki, Genetic Resources Center (MAFF), National Institute of Agrobiological Sciences, 2-1-2, Kannondai, Tsukuba, Ibaraki \\ 305-8602 Japan; and K. O'Donnell, Bacterial Foodborne Pathogens and Mycology Research Unit, United States Department of Agriculture- \\ Agricultural Research Service, NCAUR, Peoria, IL 61604
}

\begin{abstract}
Crespo, M., Arrebola, E., Cazorla, F. M., Maymon, M., Freeman, S., Aoki, T., O’Donnell, K., Torés, J. A., and de Vicente, A. 2016. Analysis of Genetic diversity of Fusarium tupiense, the main causal agent of mango malformation disease in southern Spain. Plant Dis. 100:276-286.

Mango malformation disease (MMD) has become an important global disease affecting this crop. The aim of this study was to identify the main causal agents of MMD in the Axarquía region of southern Spain and determine their genetic diversity. Fusarium mangiferae was previously described in the Axarquía region but it represented only one-third of the fusaria recovered from malformed trees. In the present work, fusaria associated with MMD were analyzed by arbitrary primed polymerase chain reaction (ap-PCR), random amplified polymorphic DNA (RAPD), vegetative compatibility grouping (VCG), a PCR screen for mating type idiomorph, and phylogenetic analyses of multilocus DNA sequence data to

identify and characterize the genetic diversity of the MMD pathogens These analyses confirmed that 92 of the isolates were $F$. tupiense, which was previously only known from Brazil and Senegal. In addition, two isolates of a putatively novel MMD pathogen were discovered, nested within the African clade of the Fusarium fujikuroi species complex. The $F$. tupiense isolates all belonged to VCG I, which was first described in Brazil, and the 11 isolates tested showed pathogenicity on mango seedlings. Including the prior discovery of $F$. mangiferae, three exotic MMD pathogenic species have been found in southern Spain, which suggests multiple independent introductions of MMD pathogens in the Axarquía region.
\end{abstract}

Mango malformation disease (MMD) is an important disease of mango (Mangifera indica L.) worldwide (Kumar et al. 1993) that affects vegetative and reproductive parts. Vegetative malformation most often occurs in young seedlings, particularly in nurseries, although it can also affect mature trees. Typical symptoms in seedlings include loss of apical dominance and swelling of axillary and vegetative buds that sprout at the internodes. Because diseased seedlings cannot be cured of abnormal vegetative growth, they have to be destroyed (Ploetz 2001). Floral malformation occurs on mature trees at flowering, resulting in enlarged inflorescence, increased panicle growth, and fruit abortion. When flowers are affected, yield loss can reach $83 \%$ (Kumar et al. 1993). Removing the affected terminals in trees with MMD has been shown to be effective, although MMD management practices vary in different mango-production countries. Alternatively, sanitation sometimes needs to be integrated with alternative measures, including fungicide application, for successful management (Freeman et al. 2014a,c).

MMD was first detected in India more than a century ago (Kumar et al. 1993; Marasas et al. 2006), and has spread to most mango-growing countries worldwide (Crespo et al. 2012; Kvas et al. 2008; Lima

Corresponding author: A. de Vicente; E-mail: adevicente@uma.es

The mention of firm names or trade products does not imply that they are endorsed or recommended by the United States Department of Agriculture (USDA) over other firms or similar products not mentioned. The USDA is an equal opportunity provider and employer.

*The $\boldsymbol{e}$-Xtra logo stands for "electronic extra" and indicates that one supplementary figure and three supplementary tables are published online.

Accepted for publication 22 July 2015.

http://dx.doi.org/10.1094/PDIS-02-15-0153-RE

(c) 2016 The American Phytopathological Society et al. 2009b; Marasas et al. 2006; Youssef et al. 2007; Zhan et al. 2010). Several Fusarium spp. within the Fusarium fujikuroi species complex (FFSC; formerly Gibberella fujikuroi species complex) (Nirenberg and O'Donnell 1998) have been shown to induce MMD (Kvas et al. 2008; Lima et al. 2012; Marasas et al. 2006; Otero-Colina et al. 2010). F. mangiferae Britz M. J. Wingf. \& Marasas is the most prevalent MMD pathogen, having been reported in South Africa, Egypt, Israel, Oman, Spain, and the United States (Britz et al. 2002; Crespo et al. 2012; Kvas et al. 2008; Ploetz 2001; Youssef et al. 2007). F. proliferatum (Matsush.) Nirenberg has been reported in Egypt, Malaysia, and China (Haggag and El-Wahab 2009; Mohamed Nor et al. 2013; Zhan et al. 2010), and F. mexicanum T. Aoki, S. Freeman, Otero-Colina, Rodr.-Alv., Fern.-Pav., R. C. Ploetz \& O'Donnell has been reported in Mexico (Otero-Colina et al. 2010; Rodríguez-Alvarado et al. 2008). Other MMD-causing Fusarium spp. include $F$. sterilihyphosum Britz Marasas \& M. J. Wingf. in South Africa and Brazil (Britz et al. 2002; Lima et al. 2009b; Steenkamp et al. 2000); F. tupiense C. S. Lima, Pfenning \& J. F. Leslie in Brazil and Senegal (Lima et al. 2012; Senghor et al. 2012); and $F$. pseudocircinatum O'Donnell \& Nirenberg in Mexico (Freeman et. al 2014b).

The various fusaria responsible for MMD have been differentiated and characterized using several genetic and molecular tools, including vegetative compatibility group (VCG) (Crespo et al. 2014; Lima et al. 2009a; Zheng and Ploetz 2002), amplified fragment length polymorphisms (AFLP) (Lima et al. 2009a), random amplified polymorphic DNA (RAPD), multilocus DNA sequence data (Lima et al. 2009b; O'Donnell et al. 1998a, 2000; Steenkamp et al. 2000; Zheng and Ploetz 2002), and identification of mating-type idiomorphs based on polymerase chain reaction (PCR) assays (Britz et al. 2002). The genetic diversity among $F$. tupiense isolates was determined by Lima et al. (2009a), who described six VCG within F. tupiense in Brazil and identified a good correlation between AFLP clusters and VCG.

Determining the identity and genetic variability of MMD-causing Fusarium spp. may provide clues to the source population, host 
range, and subsequent spread that could contribute to more effective control strategies. In a previous MMD survey in the Axarquía region of southern Spain, only 38 of 132 isolates were identified as $F$. mangiferae. They were characterized genetically using several molecular techniques and resolved as three distinct VCG (Crespo et al. 2014). Here, we extend these analyses to identify and characterize the genetic diversity and phylogenetic relationships among the nonF. mangiferae MMD isolates from Spain.

\section{Materials and Methods}

Fungal isolation and preservation. Spanish isolates were obtained from mango tree shoots and inflorescences that exhibited typical floral and vegetative malformation symptoms (Fig. 1), and were collected from 2009 to 2012 in several districts of the Axarquía region in southern Spain. Isolates were grown on potato dextrose agar (PDA; Difco Laboratories) in the dark at $25^{\circ} \mathrm{C}$. Isolates were purified as single-conidial subcultures and preserved in distilled water (Castellani 1939). In addition, mycelial disks derived from the colony margins were stored at $-80^{\circ} \mathrm{C}$ in $20 \%$ glycerol. Based on a PCR screen, using the $F$. mangiferae-specific primer pair $1-3 F / R$ (Zheng and Ploetz 2002), the 94 isolates that yielded a negative genotype were included in the present study. Several pathogenic strains of Fusarium isolated from Israel, Brazil, South Africa, and Mexico were included in this study as a reference. All isolates used (Supplementary Table S1) have been stored in the Microbiology and Plant Pathology Laboratory collection (UMAF), University of Málaga, Spain or the Agricultural Research Service Culture Collection (NRRL), National Center for Agricultural Utilization Research, Peoria, IL.

Morphological characterization. A preliminary microscopic survey of the MMD isolates was performed using the rapid cellophane tape technique described by Butler and Mann (1959). Carnation leaf agar (Iqbal et al. 2005) was used to observe conidia more uniform in size and morphology than in cultures on carbohydrate-rich media such as PDA (Leslie and Summerell 2006).

Subsequently, a detailed comparison of morphological features was conducted that included four representative $F$. tupiense isolates from Spain (UMAF F0917, UMAF F0933, UMAF F1190, and UMAF F1194), and three authentic $F$. tupiense isolates from Brazil $($ NRRL $53984=$ CML 262 ex-holotype, NRRL $53993=$ CML 383, and NRRL $53996=$ CML 389, studied and identified by Lima et al. [2012]), together with $F$. mangiferae NRRL25226 and $F$. sterilihyphosum NRRL25623 (Britz et al. 2002; Otero-Colina et al. 2010). Isolates were grown in the dark, under continuous black light (near-UV fluorescent light; National FL8BL-B 8 W/08; Panasonic) or under an ambient daylight photoperiod on PDA and synthetic nutrient-poor agar (SNA) (Nirenberg and O'Donnell 1998). Conidia and conidiophores produced in SNA cultures were examined and photographed using distilled water as the mounting medium. Morphological features of the Spanish isolates were compared with descriptions of $F$. tupiense provided by Lima et al. (2012) and those of other members of the FFSC described by Nirenberg and O'Donnell (1998) and Britz et al. (2002). Detailed examination of phenotypic characteristics and mycelial growth rates were performed according to published protocols (Aoki et al. 2003).

Pathogenicity assays. To complete Koch's postulates, pathogenicity assays were performed using 11 isolates of $F$. tupiense from Spain following the maximum diversity in terms of sample collections, UMAF F0927 Fusarium sp. (Table 1), three reference isolates (MRC7560, UMAF F0910, and UMAF F0938) of F. mangiferae, and isolate UMAF F1062 of a Fusarium sp. saprophytic on mango. Conidial suspensions used for inoculating dormant buds were prepared by growing isolates on PDA at $25^{\circ} \mathrm{C}$ in the dark for 1 week, after which conidia were harvested from the colony surface and diluted to a final concentration of $5 \times 10^{7}$ conidia/ml (Freeman et al. 1999). Sterile water was used as the negative control. Pathogenicity assays were performed on 1- to 2-year-old healthy 'Keitt' mango seedlings by inoculating five buds per isolate with $20 \mu \mathrm{l}$ of the conidial suspension. Trees were maintained in a plant growth chamber at $25^{\circ} \mathrm{C}$ with a 12-h day-and-night light cycle during the inoculation process and the first 24 to $48 \mathrm{~h}$ postinoculation. Afterward, inoculated trees were placed in a restricted area where environmental conditions were appropriate for floral induction until bud break, which was approximately 6 to 11 months after inoculation. These

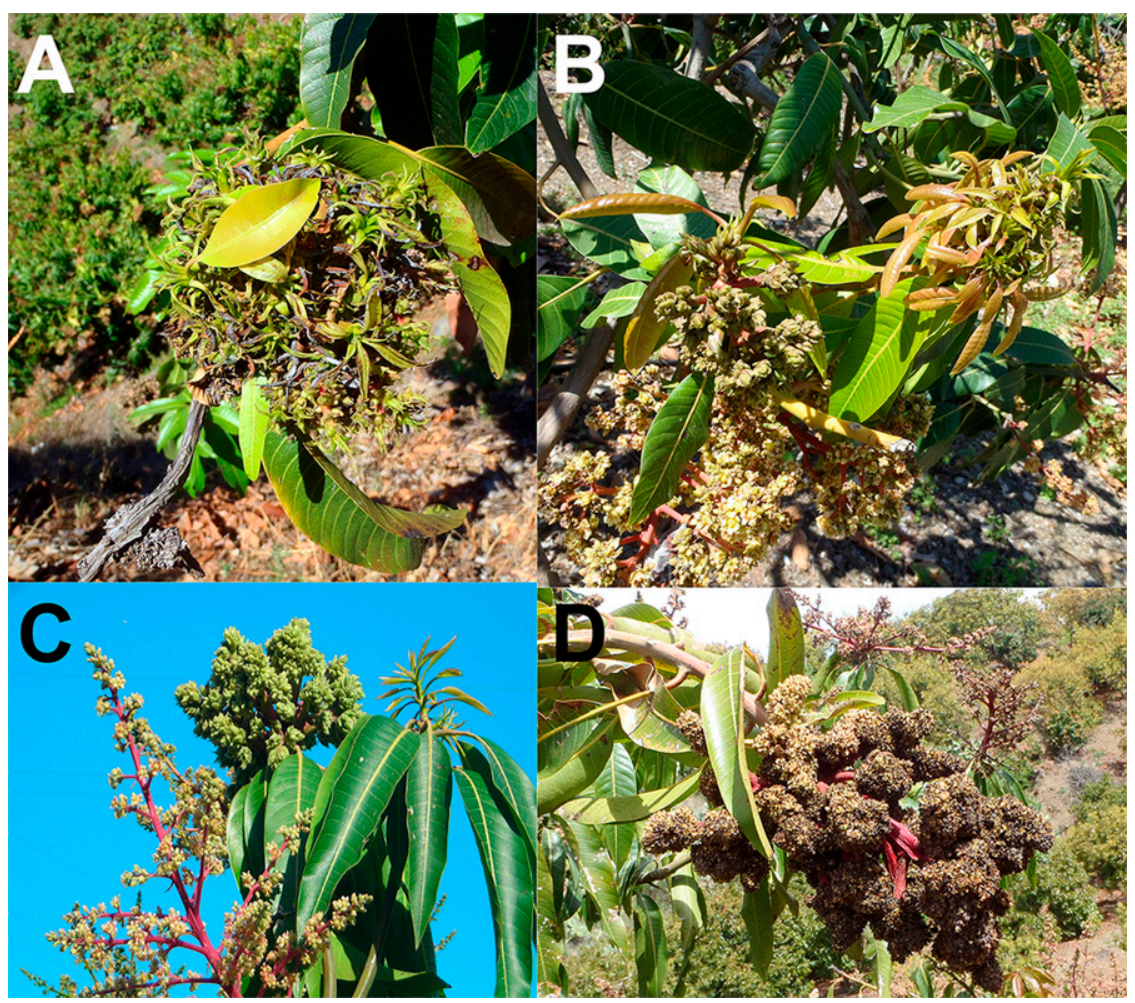

Fig. 1. Typical symptoms of mango malformation disease caused by Fusarium tupiense in commercial orchards in Southern Spain. A, Vegetative malformation. B, Branch showing floral and vegetative malformation. $\mathbf{C}$ and $\mathbf{D}$, Floral malformation. 
experiments were conducted during the winter months of 2010 and 2011 in three different assays (March and November 2010 and November 2011).

DNA isolation. Fusaria were cultured in the dark on PDA at $25^{\circ} \mathrm{C}$ for 5 to 7 days, freshly harvested mycelium was ground to a fine powder using liquid nitrogen, and DNA was extracted using a DNeasy Plant Mini Kit (Qiagen Inc.) following the manufacturer's instructions. After the DNA concentration was quantified using a NanoDrop ND-1000 spectrophotometer, each genomic DNA was diluted to $20 \mathrm{ng} / \mu \mathrm{l}$.

Table 1. Characterization of Fusarium isolates obtained from mango malformed tissues in Spain, including pathogenicity on mango, vegetative compatibility group (VCG) and arbitrary primed polymerase chain reaction (ap-PCR) genotype determination

\begin{tabular}{|c|c|c|c|c|c|c|}
\hline Species & Isolate $^{\mathrm{a}}$ & Origin & Year & Pathogenicity assays $^{b}$ & $\mathrm{VCG}^{\mathrm{c}}$ & Genotype $^{d}$ \\
\hline Fusarium sp. & UMAF F0927e & Spain (Vélez-Málaga) & 2009 & Positive & VCG D & 8 \\
\hline Fusarium sp. & UMAF F0928e & Spain (Vélez-Málaga) & 2009 & nd & VCG D & 8 \\
\hline Fusarium tupiense & UMAF F0604 & Spain (Vélez-Málaga) & 2006 & Positive & VCG I & 1 \\
\hline F. tupiense & UMAF F0606 & Spain (Vélez-Málaga) & 2006 & nd & VCG I & 1 \\
\hline F. tupiense & UMAF F0913 & Spain (Vélez-Málaga) & 2009 & nd & VCG I & 1 \\
\hline F. tupiense & UMAF F0915 & Spain (Vélez-Málaga) & 2009 & Positive & VCG I & 1 \\
\hline F. tupiense & UMAF F0916 & Spain (Vélez-Málaga) & 2009 & Positive & VCG I & 1 \\
\hline F. tupiense & UMAF F0917 & Spain (Vélez-Málaga) & 2009 & Positive & VCG I & 1 \\
\hline F. tupiense & UMAF F0930 & Spain (Algarrobo) & 2009 & Positive & VCG I & 1 \\
\hline F. tupiense & UMAF F0931 & Spain (Vélez-Málaga) & 2009 & nd & VCG I & 1 \\
\hline F. tupiense & UMAF F0933 & Spain (Vélez-Málaga) & 2009 & Positive & VCG I & 1 \\
\hline F. tupiense & UMAF F1041 & Spain (Vélez-Málaga) & 2010 & nd & VCG I & 1 \\
\hline F. tupiense & UMAF F1046 & Spain (Vélez-Málaga) & 2010 & nd & VCG I & 1 \\
\hline F. tupiense & UMAF F1047 & Spain (Vélez-Málaga) & 2010 & nd & VCG I & 1 \\
\hline F. tupiense & UMAF F1051 & Spain (Vélez-Málaga) & 2010 & nd & VCG I & 1 \\
\hline F. tupiense & UMAF F1054 & Spain (Velez-Málaga) & 2010 & nd & VCG I & 1 \\
\hline F. tupiense & UMAF F1056 & Spain (Algarrobo) & 2010 & nd & VCG I & 1 \\
\hline F. tupiense & UMAF F1060 & Spain (Algarrobo) & 2010 & nd & VCG I & 1 \\
\hline F. tupiense & UMAF F1063 & Spain (Vélez-Málaga) & 2010 & nd & VCG I & 1 \\
\hline F. tupiense & UMAF F1066 & Spain (Vélez-Málaga) & 2010 & nd & VCG I & 1 \\
\hline F. tupiense & UMAF F1067 & Spain (Benamocarra) & 2010 & nd & VCG I & 1 \\
\hline F. tupiense & UMAF F1168 & Spain (Benamargosa) & 2011 & nd & nd & 1 \\
\hline F. tupiense & UMAF F1171 & Spain (Vélez-Málaga) & 2011 & Positive & VCG I & 1 \\
\hline F. tupiense & UMAF F1177 & Spain (Algarrobo) & 2011 & nd & VCG I & 1 \\
\hline F. tupiense & UMAF F1178 & Spain (Algarrobo) & 2011 & nd & VCG I & 1 \\
\hline F. tupiense & UMAF F1179 & Spain (Algarrobo) & 2011 & nd & VCG I & 1 \\
\hline F. tupiense & UMAF F1180 & Spain (Almayate, V-M) & 2011 & nd & VCG I & 1 \\
\hline F. tupiense & UMAF F1181 & Spain (Vélez-Málaga) & 2011 & Positive & VCG I & 1 \\
\hline F. tupiense & UMAF F1182g & Spain (Vélez-Málaga) & 2011 & nd & VCG I & 7 \\
\hline F. tupiense & UMAF F1190 & Spain (Vélez-Málaga) & 2011 & Positive & VCG I & 1 \\
\hline F. tupiense & UMAF F1194 & Spain (Benamocarra) & 2011 & Positive & VCG I & 1 \\
\hline F. tupiense & UMAF F1197 & Spain (Vélez-Málaga) & 2011 & nd & VCG I & 1 \\
\hline F. tupiense & UMAF F1199 & Spain (Vélez-Málaga) & 2011 & Positive & VCG I & 1 \\
\hline F. tupiense & UMAF F12104 & Spain (Vélez-Málaga) & 2012 & nd & VCG I & 1 \\
\hline F. tupiense & UMAF F12107 & Spain (Vélez-Málaga) & 2012 & nd & VCG I & 1 \\
\hline F. tupiense & UMAF F12111 & Spain (Vélez-Málaga) & 2012 & nd & VCG I & 1 \\
\hline F. tupiense & UMAF F12112 & Spain (Vélez-Málaga) & 2012 & nd & VCG I & 1 \\
\hline F. tupiense & UMAF F12113 & Spain (Almáchar) & 2012 & nd & VCG I & 1 \\
\hline F. tupiense & UMAF F12117 & Spain (Vélez-Málaga) & 2012 & nd & VCG I & 1 \\
\hline F. tupiense & UMAF F12120 & Spain (Vélez-Málaga) & 2012 & nd & VCG I & 1 \\
\hline F. tupiense & UMAF F12121 & Spain (Benamocarra) & 2012 & nd & VCG I & 1 \\
\hline F. tupiense & UMAF F12122 & Spain (Benamocarra) & 2012 & nd & VCG I & 1 \\
\hline F. tupiense & UMAF F12128 & Spain (Benamocarra) & 2012 & nd & VCG I & 1 \\
\hline F. tupiense & UMAF F12131 & Spain (Benamocarra) & 2012 & nd & VCG I & 1 \\
\hline F. tupiense & NRRL $53984(C M L 262)^{\mathrm{h}}$ & Brazil & $\ldots$ & nd & nd & 6 \\
\hline F. tupiense & NRRL 53986 (CML266) & Brazil & $\cdots$ & nd & VCG VI & 5 \\
\hline F. tupiense & NRRL 53992 (CML350) & Brazil & $\begin{array}{l}\cdots \\
\ldots\end{array}$ & nd & VCG II & 2 \\
\hline F. tupiense & NRRL 53993 (CML383) & Brazil & $\cdots$ & nd & VCG III & 3 \\
\hline F. tupiense & NRRL 53994 (CML385) & Brazil & $\ldots$ & nd & VCG IV & 3 \\
\hline F. tupiense & NRRL 53995 (CLM386) & Brazil & $\cdots$ & nd & VCG I & 1 \\
\hline F. tupiense & NRRL 53996 (CML389) & Brazil & $\cdots$ & nd & VCG V & 4 \\
\hline
\end{tabular}

a UMAF = Microbiology and Plant Pathology laboratory collection, University of Málaga, Spain; NRRL = Agricultural Research Service Culture Collection, National Center for Agricultural Utilization Research, Peoria, IL; CML = Coleção Micológica de Lavras, Universidade Federal de Lavras, Brazil.

${ }^{\mathrm{b}}$ Positive $=$ induced $\mathrm{MMD}$ and $\mathrm{nd}=$ not determined.

c VCG of Spanish isolates determined in this study. Those from Brazil were determined previously by Lima et al. (2009a). Spanish and Brazilian isolates were tested for complementation against each other.

d Genotypes were distinguished based on identical band patterns using three different repeat motifs. The Spanish isolates of $F$. tupiense not included in this table were typed as genotype 1 .

e Two isolates of the putative novel MMD Fusarium sp. shared an identical ap-PCR banding pattern and were included in a unique VCG designated VCG D.

${ }^{f}$ UMAF F1168 was the only isolate of $F$. tupiense typed as MAT-1.

${ }^{g}$ F. tupiense UMAF F1182 showed a specific ap-PCR profile (genotype 7) that was distinct from the other F. tupiense isolates from Spain.

h The ex-holotype strain of $F$. tupiense. 
Fungal DNA PCR amplification. All of the isolates $(n=94)$ included in the present study yielded negative genotypes when they were screened with $F$. mangiferae-specific PCR primers $1-3 \mathrm{~F} / \mathrm{R}$ (forward: 5'-TGCAGATAATGAGGGTCTGC-3'; reverse: 5'GGA ACATTGGGCAAAACTAC-3') (Zheng and Ploetz 2002). PCR was performed in a total volume of $25 \mu$ l containing $1 \mu$ l of genomic DNA, $1 \mu l$ of each primer at $10 \mathrm{pmol} / \mu \mathrm{l}, 2.5 \mu \mathrm{l}$ of $10 \times$ reaction buffer (200 mM Tris-HCl [pH 8.4] and $500 \mathrm{mM} \mathrm{KCl}$ ), $0.2 \mu l$ of $10 \mathrm{mM}$ dNTP, $0.75 \mu \mathrm{l}$ of $50 \mathrm{mM} \mathrm{MgCl}_{2}$, and $0.5 \mu \mathrm{l}$ of Taq Polymerase (Invitrogen). Sterile double-distilled water $\left(\mathrm{ddH}_{2} \mathrm{O}\right)$ was added to a final volume of $25 \mu \mathrm{l}$. PCR was run in a MJ Mini Thermal cycler (Bio-Rad) or TC-412 Thermal cycler (TECHNE), starting with a 1-min denaturation step at $95^{\circ} \mathrm{C}$; followed by 40 cycles of $15 \mathrm{~s}$ of denaturing at $94^{\circ} \mathrm{C}, 30 \mathrm{~s}$ of annealing at $68^{\circ} \mathrm{C}$, and $60 \mathrm{~s}$ at $72^{\circ} \mathrm{C}$; followed by a final elongation step for $5 \mathrm{~min}$ at $72^{\circ} \mathrm{C}$. The $61-2 \mathrm{~F} / \mathrm{R}$ primer set, which was originally developed to identify $F$. subglutinans from maize (Möller et al. 1999), was included to screen for the presence of $F$. sterilihyphosum and F. mexicanum (Marasas et al. 2006; Rodríguez-Alvarado et al. 2008; Zheng and Ploetz 2002). These primers (forward: 5'-GGCCAC TCAAGAGGCGAAAG-3'; reverse: 5'-GTCAGACCAGAGCAATG GGC-3') (Möller et al. 1999) amplify a 445-bp fragment from the latter two species. PCR was performed in a total volume of $25 \mu l$ containing approximately $1 \mu \mathrm{l}$ of genomic DNA, $1 \mu \mathrm{l}$ of each primer at 10 $\mathrm{pmol} / \mu \mathrm{l}, 2.5 \mu \mathrm{l}$ of $10 \times$ reaction buffer $(200 \mathrm{mM}$ Tris- $\mathrm{HCl}$ [pH 8.4] and $500 \mathrm{mM} \mathrm{KCl}$ ), $0.2 \mu l$ of $10 \mathrm{mM} \mathrm{dNTP,} 0.75 \mu \mathrm{l}$ of $50 \mathrm{mM} \mathrm{MgCl}_{2}$, and $0.5 \mu \mathrm{l}$ of Taq DNA Polymerase. Sterile $\mathrm{ddH}_{2} \mathrm{O}$ was added to a final volume of $25 \mu \mathrm{l}$. The reactions were incubated in a MJ Mini thermal cycler starting with a 2 -min denaturation step at $95^{\circ} \mathrm{C}$; followed by 25 cycles of $60 \mathrm{~s}$ of denaturing at $95^{\circ} \mathrm{C}, 60 \mathrm{~s}$ of annealing at $65^{\circ} \mathrm{C}$, and $90 \mathrm{~s}$ at $72^{\circ} \mathrm{C}$; followed by a final elongation step for $5 \mathrm{~min}$ at $72^{\circ} \mathrm{C}$. The following reference strains were also analyzed: $F$. sterilihyphosum (NRRL 25623 ex holotype and NRRL 53569), F. mexicanum (NRRL 47473, NRRL 47485, NRRL 53571, NRRL 53575, and NRRL 53580), F. tupiense (CML 262 = NRRL 53984 ex holotype, NRRL 53993, and NRRL 53996), and $F$. mangiferae (MRC 7560).

In both PCR assays, PCR products were inspected by running 3- to 4- $\mu 1$ aliquots onto $1 \%$ agarose D1 Low EEO (Pronadisa; Conda Laboratorios) gels in $1 \times$ Tris-acetate-EDTA buffer ( $40 \mathrm{mM}$ Tris-acetate and $1 \mathrm{mM}$ EDTA) at $90 \mathrm{~V}$ for $35 \mathrm{~min}$. Gels were subsequently stained with ethidium bromide at $0.4 \mu \mathrm{g} / \mathrm{ml}$ and images were recorded using a Gel Doc XR+ (Bio-Rad). Molecular weight analysis was performed with Quantity One software (version 4.2.1; Bio-Rad) using a low DNA mass ladder (2-kb; Invitrogen) as the molecular weight marker.

To study genetic diversity, arbitrary primed (ap)-PCR analysis was conducted on DNA preparations of the 94 fusaria plus the following MMD-causing fusaria as references: $F$. mangiferae MRC 7560, $F$. sterilihyphosum NRRL 25623 ex-holotype, F. pseudocircinatum NRRL 53570, F. mexicanum NRRL53580, and $F$. tupiense NRRL 53984 ex-holotype. ap-PCR analysis was conducted with three repeat motif primers designated $(\mathrm{GACAC})_{3},(\mathrm{CAG})_{5}$, and $(\mathrm{GACA})_{4}$. All PCR assays were performed as previously described (Otero-Colina et al. 2010) in $20 \mu$ l containing $1 \mu$ l of genomic DNA, $2 \mu 1$ of $10 \times$ buffer containing $50 \mathrm{mM} \mathrm{KCl}$ and $10 \mathrm{mM}$ Tris- $\mathrm{HCl}, 2 \mu \mathrm{l}$ of $1.5 \mathrm{mM} \mathrm{MgCl}_{2}$, $0.2 \mu \mathrm{l}$ of Taq DNA Polymerase (Promega Corp.), $2 \mu l$ of dNTP (containing $0.2 \mathrm{mM}$ each dNTP), and $1 \mu \mathrm{l}$ of each primer at $10 \mathrm{pmol} / \mu \mathrm{l}$. Reactions were run on a PYC-1000 thermocycler (MJ Research, Inc.) starting with $1 \mathrm{~min}$ of denaturation at $95^{\circ} \mathrm{C}$; followed by 30 cycles of $30 \mathrm{~s}$ at $95^{\circ} \mathrm{C}, 30 \mathrm{~s}$ at either $60^{\circ} \mathrm{C}$ for $(\mathrm{CAG})_{5}$ or $48^{\circ} \mathrm{C}$ for $(\mathrm{GACAC})_{3}$ and (GACA $)_{4}$, and $90 \mathrm{~s}$ at $72^{\circ} \mathrm{C}$; with a final elongation step for $15 \mathrm{~min}$ at $72^{\circ} \mathrm{C}$ for $(\mathrm{CAG})_{5}$ or $10 \mathrm{~min}$ at $72^{\circ} \mathrm{C}$ for $(\mathrm{GACAC})_{3}$ and $(\mathrm{GACA})_{4}$. Amplification products were separated on $1.5 \%$ agarose gels run in Tris-acetate-EDTA buffer electrophoresed at $80 \mathrm{~V}$ for $2 \mathrm{~h}$. Following ethidium bromide staining, Quantity One software (version 4.2.1; Bio$\mathrm{Rad}$ ) was used to analyze the amplicon sizes with the GeneRuler 1-kb DNA ladder (Invitrogen).

To explore whether the homogeneous band pattern obtained by ap-PCR from all the Spanish F. tupiense isolates could be differentiated by another technique, a RAPD-PCR assay was carried out with some Spanish MMD isolates, including F. tupiense (UMAF F0915, UMAF F0916, UMAF F0917, UMAF F0933, UMAF F1190, and
UMAF F1194) collected from floral and vegetative symptoms in different orchards and year of isolation, Fusarium sp. UMAF F0927, and six Spanish isolates of $F$. mangiferae of different genotypes and VCG (Crespo et al. 2014). Also included in this study were several reference isolates of $F$. mangiferae, $F$. sterilihyphosum, $F$. mexicanum, and, in particular, $F$. tupiense Brazilian isolates representing the six genotypes previously described by Lima et al. (2009a). RAPD-PCR analysis was conducted in similar reaction mixtures as described for ap-PCR analysis using two10-base primers: OPF-08 (GGGATATCGG) and OPF-13 (GGCTGCAGAA) (Kit F; Operon Technologies). For RAPD-PCR, the initial denaturation step of $95^{\circ} \mathrm{C}$ was followed by 45 cycles of $1 \mathrm{~min}$ at $94^{\circ} \mathrm{C}, 1 \mathrm{~min}$ at $34^{\circ} \mathrm{C}$, and 2 min at $72^{\circ} \mathrm{C}$, ending with a final elongation step for $15 \mathrm{~min}$ at $72^{\circ} \mathrm{C}$. Amplification products were visualized as described above. Isolates that showed identical banding patterns with ap-PCR and, eventually, RAPD-PCR primers were assigned to a genotype. All PCR experiments were conducted at least four times with identical results.

Finally, a PCR assay to identify mating-type idiomorph was used to screen the Spanish isolates $(n=94)$ (Kerényi et al. 1999; Steenkamp et al. 2000) using the primer pairs GFmat la and GFmat $1 \mathrm{~b}$ (forward: 5'-GTTCATCAAAGGGCAAGCG-3'; reverse: 5'-TAA GCGCCCTCTTAACGCCTTC-3') for MAT1-1 and GFmat2c and GFmat2d (forward: 5'-AGCGTCATTATTCGATCAAG-3'; reverse: 5'-CTACGTTGAGAGCTGTACA-3') for MAT1-2 (Steenkamp et al. 2000). All PCR assays were performed in a total volume of $20 \mu \mathrm{l}$ containing $1.5 \mu \mathrm{l}$ of genomic DNA, $0.5 \mu \mathrm{l}$ of each primer at 10 $\mathrm{pmol} / \mu \mathrm{l}, 2 \mu \mathrm{l}$ of $10 \times$ reaction buffer containing $200 \mathrm{mM}$ Tris- $\mathrm{HCl}$ (pH 8.4) and $500 \mathrm{mM} \mathrm{KCl}, 2 \mu \mathrm{l}$ of dNTP, $2 \mu \mathrm{l}$ of $1.5 \mathrm{mM} \mathrm{MgCl}{ }_{2}$, and $0.2 \mu \mathrm{l}$ of $\mathrm{Taq}$ DNA Polymerase (Invitrogen). Sterile $\mathrm{ddH}_{2} \mathrm{O}$ water was added to a total volume of $20 \mu \mathrm{l}$. PCR assays were run on a PYC-1000 thermocycler starting with a denaturation step at $94^{\circ} \mathrm{C}$ for $1 \mathrm{~min}$; followed by 34 cycles consisting of $30 \mathrm{~s}$ at $92^{\circ} \mathrm{C}, 30 \mathrm{~s}$ at $67^{\circ} \mathrm{C}$, and $30 \mathrm{~s}$ at $72^{\circ} \mathrm{C}$; and ending with a final elongation step for $5 \mathrm{~min}$ at $70^{\circ} \mathrm{C}$. Amplicons were separated on $1.2 \%$ agarose gels in Trisacetate-EDTA buffer electrophoresed at $100 \mathrm{~V}$ for 20 to $30 \mathrm{~min}$. Gels were subsequently stained with ethidium bromide and documented with a Gel Doc XR+ imaging system (Bio-Rad). Molecular-weight analysis of amplicons was performed with Quantity One software (version 4.2.1; Bio-Rad), using the GeneRuler 100-bp DNA ladder (Invitrogen) as a molecular-weight marker.

Vegetative compatibility. VCG was determined for 41 representative $F$. tupiense and the two Fusarium sp. isolates from Spain (Table 1), including a collection of six $F$. tupiense reference isolates corresponding to six VCG described for this species by Lima et al. (2009a) and the following five reference strains: $F$. mangiferae MRC7560, F. sterilihyphosum NRRL25623 and NRRL53569, and F. mexicanum NRRL47473 and NRRL53580. Nitrate-nonutilizing (nit) auxotrophic mutants were generated for all of the strains, as described previously (Correll et al. 1987). Briefly, nit mutants were generated by transferring four small plugs from the colony edge on PDA to petri dishes ( $90 \mathrm{~mm}$ in diameter) containing minimal medium $(\mathrm{MM})+\mathrm{ClO}_{3}$. The initial $\mathrm{KClO}_{3}$ level in the $\mathrm{MM}$ was $15 \mathrm{~g} /$ liter. However, when isolates failed to form mutants on this medium, the chlorate concentration was increased to $\mathrm{KClO}_{3}$ at $25 \mathrm{~g} /$ liter. Resistant sectors were subcultured onto $\mathrm{MM}$ with $\mathrm{NaNO}_{3}$ when they were detected. Strains that grew as thin, expansive colonies on MM were scored as nit mutants and they were stored in distilled water for subsequent analysis. Strains with intense growth that resembled the wild type were discarded. Based on their growth on MM containing different nitrogen sources $\left(\mathrm{MM}+\mathrm{NaNO}_{3}, \mathrm{MM}+\mathrm{NaNO}_{2}, \mathrm{MM}+\right.$ hypoxanthine, and $\mathrm{MM}+$ ammonium tartrate), nit mutants were assigned to different phenotypic classes defined previously by Correll et al. (1987). Initially, L-asparagine at $1.6 \mathrm{~g} /$ liter was added to the $\mathrm{MM}$ for producing nit mutants as an alternative nitrogen source but L-asparagine was replaced by L-threonine at $1.4 \mathrm{~g} /$ liter in later experiments. The change from L-asparagine to L-threonine resulted in an increase in the percentage of NitM mutants recovered (Klittich and Leslie 1988).VCG were determined by visual inspection of plates for complementation via heterokaryon formation by the nit mutants. 
Complementation tests were performed on MM by mycelial pairings from different phenotypic classes on 90-by-15-mm petri dishes incubated at $25^{\circ} \mathrm{C}$ (Leslie and Summerell 2006). Heterokaryon formation was evaluated after 5 to 7 days. All vegetative compatibility tests were conducted at least twice.

DNA sequencing and phylogenetic analysis of MMD-associated Fusarium spp. To obtain genomic DNA for the multilocus molecular phylogenetic analyses, isolates were grown in $50 \mathrm{ml}$ of yeast-malt broth ( $20 \mathrm{~g}$ of dextrose, $5 \mathrm{~g}$ of peptone, $3 \mathrm{~g}$ of yeast extract, and $3 \mathrm{~g}$ of malt extract per liter; Difco Laboratories) in 300-ml Erlenmeyer flasks on a rotary shaker at $100 \mathrm{rpm}$ for 2 to 3 days. Mycelium was harvested over a Büchner funnel onto Whatman number $170-\mathrm{mm}$ filter paper (Schleicher and Schuell) and freeze dried. Total genomic DNA was extracted from freeze-dried mycelium using a hexadecyltrimethyl-ammonium bromide (Sigma-Aldrich) protocol, as previously described (O'Donnell et al. 1998a). Portions of the following seven loci were PCR amplified and sequenced (Table 2), as previously described (O'Donnell et al. 1998a, 2000, 2013): $\beta$-tubulin, calmodulin, translation elongation factor (TEF1), histone H3, RNA polymerase subunits $R P B 1$ and $R P B 2$, and the nuclear ribosomal intergenic spacer region (IGS rDNA). Platinum Taq DNA polymerase (Invitrogen Life Technologies) was used for all PCR, and DNA sequencing was conducted using Applied Biosystems BigDye (version 3.1; ABI) in an ABI 9700 thermocycler, as previously reported (O'Donnell et al. 1998b). Nuclear IGS rDNA was sequenced with the following four internal sequencing primers: iNL11 $5^{\prime}$ AGGCTTCGGCTTAGCGTCTTAG, NLa 5'-AGGCTTCGGCTT AGCGTCTTAG, iCNS1 5'-TTTCGCAGTGAGGTCGGCAG, and CNSa 5'-TCTCATRTACCCTCCGAGACC (O'Donnell et al. 2000). After ABI chromatograms were edited and aligned with Sequencher (version 4.1.2; Gene Codes), TextPad version 5.1.0 for Windows (http://www.textpad.com/) was used to manually improve alignments for the phylogenetic analyses.

Unweighted maximum parsimony (MP) analysis of the sevenlocus $9.1-\mathrm{kb}$ dataset (Table 2) was implemented in PAUP* $4.0 \mathrm{~b} 10$ (Swofford 2003) using the heuristic search option, 1,000 random addition sequences with MULPARS on, and tree bisectionreconnection branch swapping. MrModeltest version 2.2 (Posada and Crandall 1998) identified the general-time-reversible model with a proportion of invariant sites and $\gamma$ distributed rate heterogeneity $(\mathrm{GTR}+\mathrm{I}+\Gamma)$ as the best-fit model of nucleotide substitution for the maximum likelihood bootstrap (ML-BS) analysis, which was conducted on the CIPRES Science Gateway (https://www.phylo.org/) using GARLI 2.01 (Zwickl 2006). Sequences of two members of the $F$. oxysporum species complex, NRRL 22902 and 20433, were used to root the phylogeny based on more inclusive analyses (O'Donnell et al. 1998a, 2013). Clade support was assessed by MP-BS in PAUP*, employing 1,000 pseudoreplicates of the data, tree bisection and reconnection (TBR) branch swapping, MAXTREES set to automatically increase by 100 , and 10 random taxon-addition sequences per replicate; and by 1,000 nonparametric ML-BS replicates using GARLI 2.01 on the CIPRES Science Gateway.
Nucleotide sequence accession numbers. GenBank accession numbers for the DNA sequences determined in this study are KP753386 to KP753446.

\section{Results}

Identification of MMD isolates from Spain. The 92 fusaria isolates recovered from malformed tissue yielded a negative genotype using the F. mangiferae-specific PCR assay; however, a 445-bp DNA fragment was amplified with the $61-2 \mathrm{~F} / \mathrm{R}$ primer pair, and they showed general FFSC morphological features in culture on PDA and SNA. Microscopic analysis of these isolates identified them as F. tupiense (Lima et al. 2012) (Fig. 2). Based on a detailed comparative morphological study together with the representative strains, we prepared a morphological description of $F$. tupiense Spanish isolates (Fig. 2).

Colonies grown on PDA showed mycelial growth rates of 3.6 to $4.7 \mathrm{~mm} /$ day at $20^{\circ} \mathrm{C}$ in the dark. Aerial mycelia was sparse to abundant, loosely to densely floccose, and sometimes funiculose. Colonies varied from white to purplish. Sclerotial bodies and chlamydospores were absent. Sporulation on SNA in the dark started early in the aerial mycelium but sporodochial conidia were produced sparsely or not at all. Under black light, sporulation became abundant in the aerial mycelium and in sporodochia. Sporodochia we observed on or in the agar. Coiled sterile hyphae in $F$. tupiense isolates from Spain were not observed. Aerial conidiophores were almost prostrate in the dark, unbranched or sparsely branched sympodially or verticillately, terminated in mono- or polyphialides, and formed short clavate to ellipsoidal straight or reniform zero to one (or two)-septate conidia in false heads. Under black light, aerial conidiophores were typically erect and sympodially or verticillately branched, and often formed compactly branched, dendroid structures that terminated in mono- or polyphialides forming conidia in false heads. Nonseptate conidia measured 4 to 19 by 1.5 to $3.5 \mu \mathrm{m}$ in the dark and 6 to 18.5 by 1.5 to $5.5 \mu \mathrm{m}$ under black light, and single-septate conidia were 11 to 46 by 2 to $4.5 \mu \mathrm{m}$ under black light. Ellipsoid to fusiform or boatshaped three (to four)-septate conidia with a truncate base also formed abundantly on aerial conidiophores under black light, and 3 -septate aerial conidia were 25.5 to 50 by 2.5 to $4.5 \mu \mathrm{m}$. Sporodochial conidia were (one to ) three to five (to seven) septate, falcate, and curved dorsiventrally. These conidia were often slender and cylindrical, and gradually tapered toward both ends, with an acuminate apical cell and a foot-like basal cell. Sporodochia formed mostly on or in the agar. Three-septate conidia measured 20 to 55.5 by 2 to $3.5 \mu \mathrm{m}$ in the dark and 27 to 71.5 by 2.5 to $4.5 \mu \mathrm{m}$ under black light, and five-septate conidia were 43.5 to 82.5 by 2 to $5.5 \mu \mathrm{m}$ under black light.

Morphological features of the Spanish isolates matched the description of $F$. tupiense by Lima et al. (2012), except for the absence of coiled sterile hyphae, which appears to be an unstable characteristic for this species. Though not noted by Lima et al. (2012), it was discovered that all isolates of $F$. tupiense, including the exholotype NRRL 53984, commonly produced erect and extensively branched aerial conidiophores on SNA under black light that

Table 2. Summary of marker loci and tree statistics for the nine individual partitions and combined dataset

\begin{tabular}{|c|c|c|c|c|c|c|c|c|}
\hline Locus & Size (bp) & MPT $^{\mathbf{a}}$ & Tree length & $\mathbf{C I}^{\mathbf{b}}$ & $\mathbf{R I}^{\mathbf{c}}$ & $\mathbf{A U T}^{\mathbf{d}}$ & PIC $^{e}$ & Total PIC (\%) \\
\hline Intergenic spacer region rDNA & 2,683 & 45 & 1,719 & 0.55 & 0.74 & 266 & 568 & 46.2 \\
\hline Histone $\mathrm{H} 3$ & 641 & 8 & 201 & 0.70 & 0.79 & 41 & 70 & 5.7 \\
\hline$\beta$ Tubulin $($ benA $)$ & 1,211 & $>100$ & 241 & 0.86 & 0.93 & 86 & 99 & 8.1 \\
\hline Translation elongation factor 1 & 664 & 15 & 254 & 0.82 & 0.85 & 96 & 82 & 6.7 \\
\hline Calmodulin & 677 & $>100$ & 137 & 0.89 & 0.94 & 52 & 61 & 5.0 \\
\hline RNA polymerase II subunit 1 & 1,617 & 15 & 344 & 0.79 & 0.91 & 86 & 164 & 13.3 \\
\hline RNA polymerase II subunit 2 & 1,797 & 2 & 570 & 0.61 & 0.69 & 129 & 185 & 15.5 \\
\hline Combined & 9,110 & 45 & 3,523 & 0.68 & 0.79 & 756 & 1,229 & 100 \\
\hline
\end{tabular}

\footnotetext{
a Most-parsimonious trees.

b Consistency index.

c Retention index.

d Autapomorphy, a derived characteristic unique to a particular taxon.

e Parsimony-informative or shared derived characteristic (PIC).
} 
typically resemble a compact dendroid structure (Fig. 2E to I). By contrast, when cultured on SNA in the dark, F. tupiense formed unbranched or sparsely branched prostrate aerial conidiophores (Fig. $2 \mathrm{~A}$ to D). Three- to four-septate ellipsoid, fusiform to boat-shaped conidia with a truncate base were commonly observed that occasionally curved or had a pointed apex when cultivated under black light (Fig. 2E, F, and L to O).

Pathogenicity of Fusarium spp. isolates on mango from Spain. We artificially inoculated mango seedlings with representative isolates (Table 1) and detected MMD symptoms after bud break in March 2011 on seedlings inoculated in March and November
2010 and March 2012 on seedlings inoculated in November 2011. Vegetative and floral malformation symptoms developed on vegetative buds of mango seedlings inoculated with the 11 F. tupiense (Fig. 3; Table 1), Fusarium sp. UMAF F0927, and F. mangiferae control strains (Supplementary Table S2). Isolates recovered from symptomatic tissue at the end of the experiment were morphologically identical to those that were inoculated and their identity was confirmed by PCR assays with $1-3 F / R$ and $61-2 F / R$ primers, successfully fulfilling Koch's postulates. Negative controls as well as the saprophytic isolate UMAF F1062 produced no symptoms.

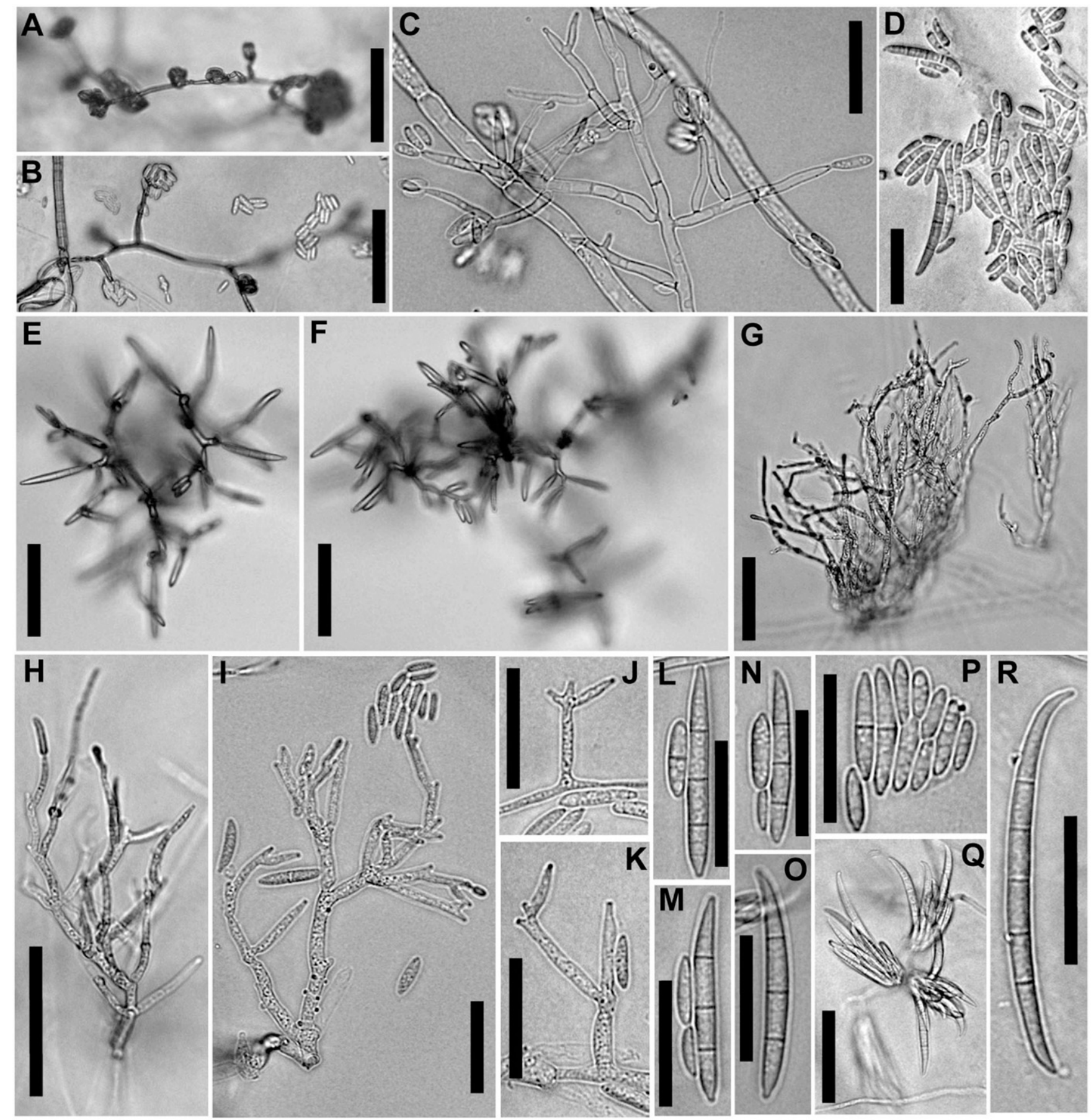

Fig. 2. Morphological characteristics of Fusarium tupiense isolates from Spain on synthetic nutrient-poor agar (SNA) A to D, in darkness and $\mathbf{E}$ to $\mathbf{R}$, under black light. A to C, Aerial conidia in false heads. D, Aerial and sporodochial conidia. E to H, Dendroid aerial conidiophores. I to K, Mono- and polyphialides in the aerial mycelium. $\mathrm{L}$ to $\mathbf{O}$, Fusiform one- to three-septate conidia with a pointed apex and truncate base. P, Zero- or one-septate oblong to elliptical aerial conidia. Q, Sporodochial conidiophores producing multiseptate conidia. $\mathbf{R}$, Three- to five-septate fusiform sporodochial conidia with an acute apical cell and foot cell. Micrographs were from Spanish isolates of $F$. tupiense UMAF F0917 ( $G$ and H), UMAF F0933 (D to F), UMAF F1190 ( $A, B$, and I to R), and UMAF F1194 (C to E). Scale bars: A, B, E to $H$, and $Q=50 \mu \mathrm{m} ; \mathrm{C}, \mathrm{D}, \mathrm{I}$ to $\mathrm{P}$, and $\mathrm{R}=25 \mu \mathrm{m}$. 
Genotyping MMD isolates from Spain. Ninety-one $F$. tupiense isolates from Spain showed a uniform and diagnostic fragment pattern, with the repeat motif ap-PCR primers $(\mathrm{GACAC})_{3},(\mathrm{CAG})_{5}$, and (GACA) $)_{4}$ here designated as genotype 1 (Fig. 4; Table 1; Supplementary Fig. S1; Supplementary Table S3). The only exception among the $F$. tupiense Spanish isolates was UMAF F1182 isolate (Table 1, genotype 7). The banding pattern (genotype 1) also distinguished the $F$. tupiense isolates from the $F$. pseudocircinatum NRRL53570, F. mangiferae MRC7560, F. sterilihyphosum NRRL 25623, and $F$. mexicanum NRRL 53580 reference isolates and also from the Brazilian NRRL 53984 (= CML 262) ex-type strain of $F$. tupiense. When we compared, by ap-PCR and RAPD-PCR, the Spanish $F$. tupiense isolates with representative isolates of the six different genotypes and VCG described by Lima et al. (2009a, 2012) in Brazil, we found that the pattern band of the named genotype 1 of $F$. tupiense is shared by the Spanish isolates and the Brazilian VCG I isolate NRL 53995 (= CML 386). This genotype showed some characteristic bands in ap-PCR profile but the presence of a specific band (number 18) from the RAPD-PCR profile is noticeable (Fig. 4). RAPD primers OPF-08 and OPF-13 also successfully distinguished the representative isolates of $F$. tupiense from Spain from the other MMD pathogens. Isolate UMAF 1182 showed a clearly differentiated ap-PCR pattern from the rest of Spanish and Brazilian isolates. Fusarium spp. isolates UMAF F0927 and F0928 also showed apPCR (two specific bands) and RAPD (one band) specific patterns (genotype 8), clearly distinct from the other MMD tested (Fig. 4; Table 1).

We generated nit mutants for all 43 isolates subjected to VCG analysis. All $41 \mathrm{~F}$. tupiense representative isolates were typed as VCG I together with the $F$. tupiense isolate NRRL53995 from Brazil (Table 1; Fig. 5). Complementation with the other reference strains from Brazil was not observed. The $F$. tupiense isolate UMAF F1182 also grouped in VCG I, even though ap-PCR typed it as the singleton genotype 7 (Table 1). None of the $F$. tupiense nit mutants from Spain were complemented by the $F$. mangiferae, $F$. sterilihyphosum, and

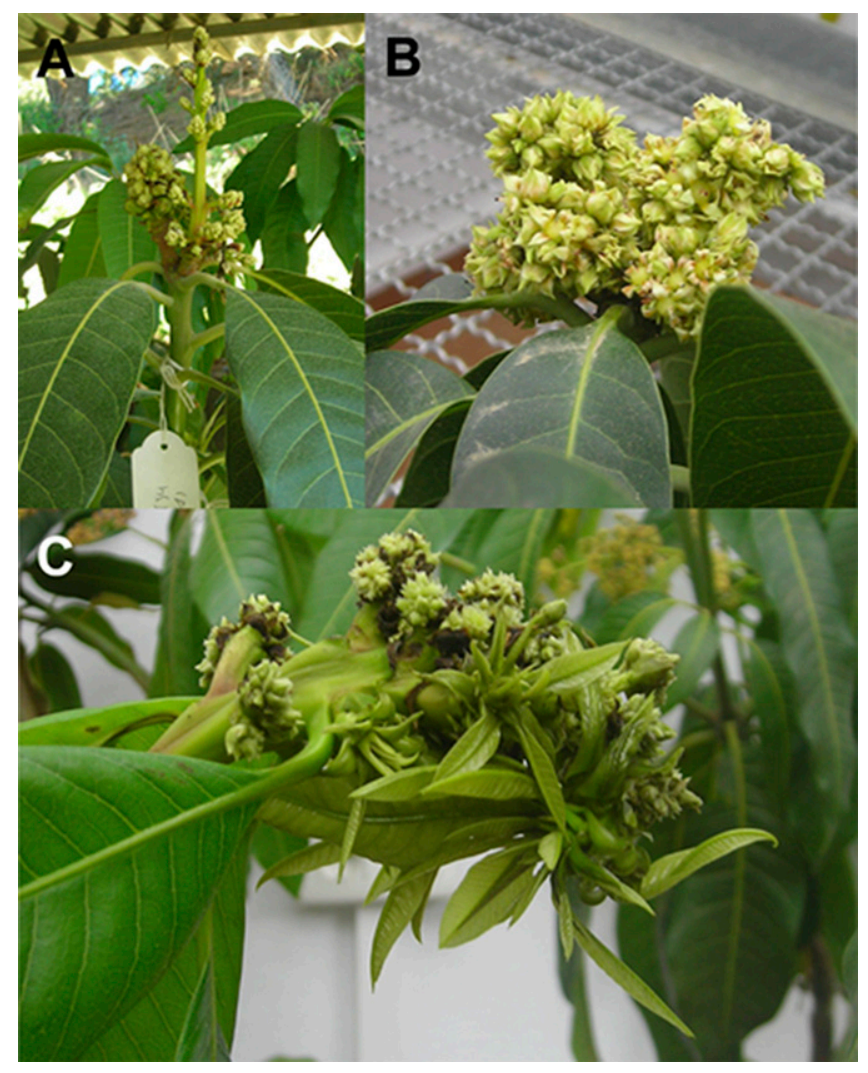

Fig. 3. Pathogenicity test on mango trees artificially inoculated with Spanish isolates of Fusarium tupiense. Floral malformation induced by isolates A, UMAF F0604 and B, UMAF F0930. C, Vegetative and floral malformation induced by UMAF F0933.
F. mexicanum reference isolates, which were included as negative controls. VCG analysis of the Spanish Fusarium spp. UMAF F0927 and F0928 isolates revealed that they belonged in a unique group designated VCG D (Table 1).

PCR assays for MAT1-1 and MAT1-2 idiomorph revealed that all of the $F$. tupiense isolates from Spain were MAT1-2, except for UMAF F1168, which was identified as MAT1-1 (Table 1). The MAT idiomorph could not be amplified in 10 of the $92 \mathrm{~F}$. tupiense isolates. This assay also established that Fusarium spp. UMAF F0927 and F0928 were MAT1-2.

Phylogenetic diversity of Spanish MMD pathogens. We analyzed a seven-locus, 9.1-kb dataset that included 26 isolates within the FFSC to investigate evolutionary relationships and species identity of seven MMD-associated isolates from Spain. Sequences of five different MMD pathogens within the FFSC were included as a reference. These included the ex-type strain of $F$. tupiense NRRL $53984=$ CML 262 from Brazil, F. mangiferae from India, $F$. sterilihyphosum from South Africa, and $F$. pseudocircinatum and $F$. mexicanum from Mexico (Fig. 6). MP analyses of the individual partitions and the combined dataset revealed that the IGS rDNA was the most informative locus, with 568 parsimony informative characteristics (Table 2). Unweighted MP analysis of the combined dataset found 45 mostparsimonious trees 3,523 steps in length that only differed in minor rearrangements within F. mangiferae and F. tupiense (Fig. 6). Monophyly of the biogeographically structured Asian, African, and American clades of the FFSC was strongly supported by MP- and ML-BS (MP-BS\ML-BS $=100 \%$ ), as was a sister group relationship of the

A $\begin{array}{llllllllllll}M M & 1 & 2 & 3 & 4 & 5 & 6 & 7 & 8 & 9 & 10 & 11\end{array}$

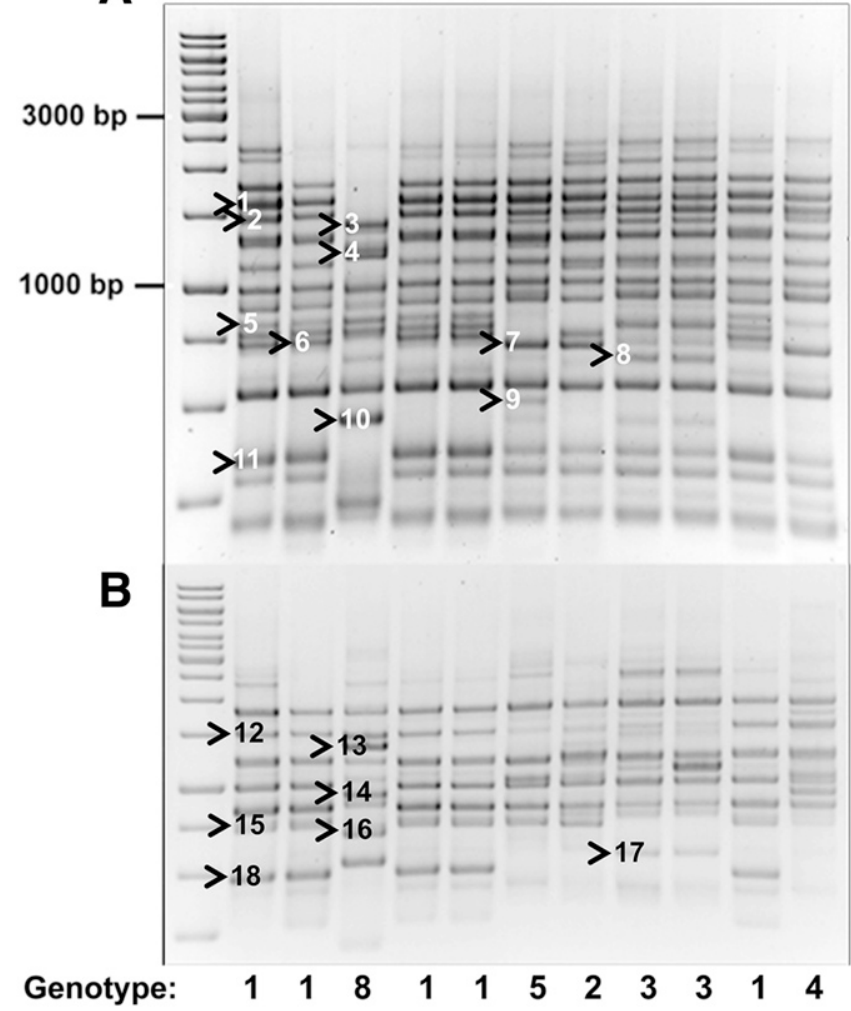

Fig. 4. Arbitrary primed (ap) and random amplified polymorphic DNA (RAPD) polymerase chain reaction (PCR) analysis of Fusarium tupiense isolates from Spain and Brazil. Band patterns generated from A, ap-PCR analysis using the (GACA) repeat motif and B, RAPD-PCR analysis using the OPF-08 primer pair. Lanes 1 to 2 and 4 to 5 , representative $F$. tupiense isolates from Spain (UMAF F0915, UMAF F0916, UMAF F0933, and UMAF F1194); lane 3, Fusarium sp. (UMAF F0927); lanes 6 to 11, representative $F$. tupiense isolates of the different genotypes described by Lima et al. (2009a) in Brazil (NRRL53986, NRRL53992, NRRL53993, NRRL53994, NRRL53995, and NRRL53996). Codes of numbers marked on the apPCR and RAPD-PCR gels correspond to the bands defining genotype. Note that the $F$. tupiense isolates from Spain share the same banding pattern as NRRL 53995 from Brazil (lane 10). MM: 1-kb DNA ladder. 
African and Asian clades (MP-BS\ML-BS = 89184\%). The primary etiological agent of MMD in Spain was identified phylogenetically as $F$. tupiense, which formed a genealogically exclusive lineage with the ex-type strain CML 262 from Brazil within the American clade with $100 \%$ MP-BS\ML-BS support (Fig. 6). The four isolates of $F$. tupiense from Spain were resolved in the combined phylogenetic analysis as three closely related multilocus sequence types. Two of the MMD-associated isolates from Spain were identified as $F$. mangiferae, which is nested within the Asian clade of the FFSC; it formed an exclusive group with the reference isolate NRRL 25226 of this mango species exhibiting MMD symptoms in India (MP-BS $\backslash$ ML-BS $=100 \%$ ). Results of the phylogenetic analyses (Fig. 6) and BLASTn queries of the National Center for Biotechnology Information (NCBI) GenBank strongly indicate that the Spanish mango isolate UMAF-F0927 represents a novel species within the African clade of the FFSC. A sister group relationship of this isolate with its near relatives NRRL 22949 F. udum E. J. Butler and NRRL 13617 F. phyllophilum Nirenberg \& O'Donnell was not supported by bootstrapping (ML-BS\ML-BS $=57 \backslash 52 \%$ ). In addition, the top matches obtained by conducting BLASTn searches of NCBI GenBank, using TEF1 and histone H3 sequences of UMAFF0927 Fusarium sp. as the query, only showed $97 \%$ identity to $F$. udum (TEF1: JF740788.1, H3: AM295807.1), F. phyllophilum (TEF1: AB674283.1, H3: KF466366.1), and $F$. xylarioides Steyaert (TEF1: AY707120.1, H3: AM295270.1). We also examined UMAF F0927 Fusarium sp. in culture on PDA and SNA in the dark and under black light at $20^{\circ} \mathrm{C}$. The morphology of this strain did not correspond to that of F. phyllophilum, F. xylarioides, or F. udum (Geiser et al. 2005; Gerlach and Nirenberg 1982; Nirenberg and O'Donnell 1998), because UMAF F0927 formed dominantly false heads and infrequently short chains of clavate aerial conidia on SNA in the dark and under black light without production of chlamydospores. Conidial chains of the fungus were formed on polyphialides but displaced and arranged in a side-by-side adhesion, termed "false chains" by Nirenberg and O'Donnell (1998). On SNA, the fungus produced abundant sporodochia under black light and a few sporodochial conidia from conidiophores formed directly on running hyphae in the dark. UMAF F0927, then, was differentiated clearly at first from

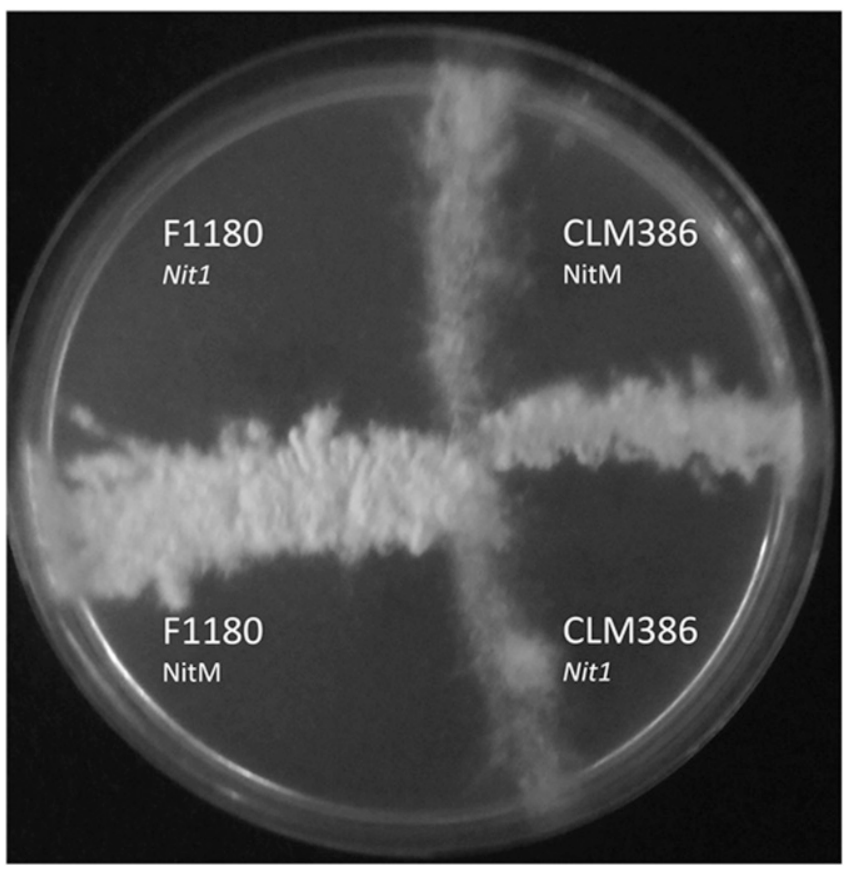

Fig. 5. Vegetative compatibility group (VCG) determination of Fusarium tupiense isolates. Complementation of nitrate-nonutilizing nit 1 and NitM mutants of F. tupiense UMAF F1180 from Spain and NRRL53995 (CML386) from Brazil growing on minimal medium containing $\mathrm{NaNO}_{3}$ as the sole nitrogen source. Robust mycelial growth indicates complementation between these two VCG I isolates.
F. xylarioides by forming polyphialides but no strongly curved, C-shaped conidia typical of the latter species (Geiser et al. 2005; Gerlach and Nirenberg 1982). F. udum formed only false heads and abundant chlamydospores but no conidial chains (Gerlach and

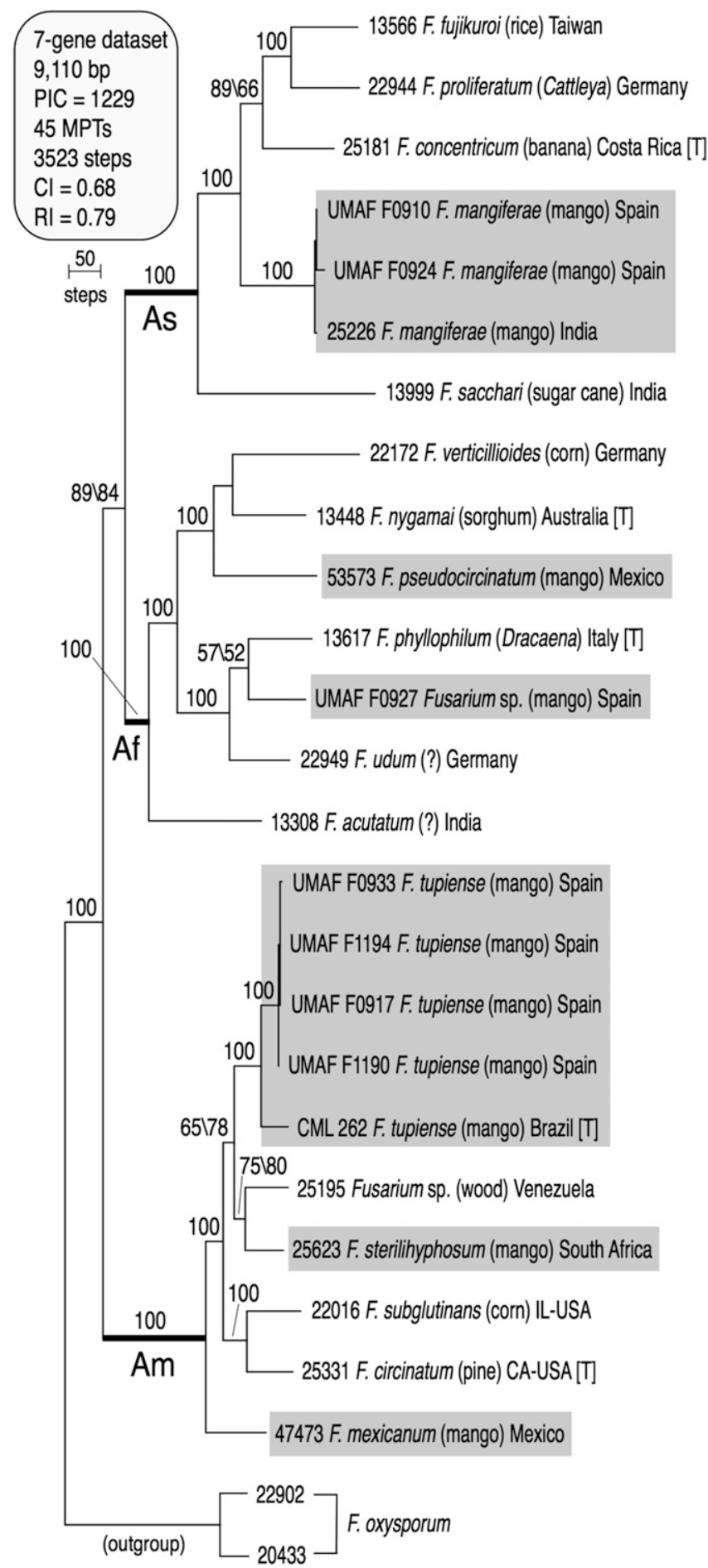

Fig. 6. One of 45 most-parsimonious trees (MPT) inferred from the combined sevenlocus, 26-taxon data set rooted on outgroup sequences of Fusarium oxysporum. Maximum parsimony and maximum likelihood bootstrap support (MP-BS/ML-BS) based on 1,000 pseudoreplicates of the data are indicated above nodes. Only one value is presented when the MP and ML bootstrap intervals were identical. The 12 isolates representing six species recovered from mango trees exhibiting mango malformation disease (MMD) symptoms are highlighted in gray. Note that Spanish isolates of $F$. tupiense (UMAF F0917, UMAF F0933, UMAF F1190, and UMAF F1194), F. mangiferae (UMAF F0910 and UMAF F0924), and a putatively novel MMD pathogen represented by UMAF F0927 Fusarium sp. are nested, respectively, within the American (Am), Asian (As), and African (Af) clades of the F. fujikuroi species complex (O'Donnell et al. 1998a). $\mathrm{Cl}=$ consistency index, $\mathrm{PIC}=$ parsimony informative characteristic, and $\mathrm{RI}=$ retention index. 
Nirenberg 1982; Nirenberg and O'Donnell 1998). Morphologically, the species most closely related to UMAF F0927 is $F$. phyllophilum, and both species formed false heads and short chains of clavate conidia from polyphialides on SNA, without chlamydospores. However, arrangement of conidial chains in UMAF F0927 is different from that of $F$. phyllophilum and represented a side-by-side adhesion of displaced conidia, suggesting similar morphology of $F$. pseudocircinatum (Nirenberg and O'Donnell 1998). In contrast, conidial chains of $F$. phyllophilum are short (less than 15 conidia) but rather linear in a top-to-bottom connection, and are formed very frequently in the dark and under black light (Gerlach and Nirenberg 1982 as $F$. proliferatum var. minus; Nirenberg and O'Donnell 1998), based on the comparative examination of the ex-type strain NRRL 13617. F. phyllophilum formed no sporodochial conidia in the dark.

\section{Discussion}

In addition to the previously described presence of $F$. mangiferae as a causal agent of MMD in Spain (Crespo et al. 2012, 2014), in this study, we recovered two other morphologically and phylogenetically distinct Fusarium spp. from MMD-affected mango trees in southern Spain and both proved to be pathogenic in mango inoculation assays. Most of these isolates $(n=92)$ were conclusively identified as $F$. tupiense based on morphological and molecular analyses. Thus, $F$. tupiense appears to represent the most prevalent causal agent of MMD in Spain. Results of the present study also indicate that a putatively novel species within the African clade of FSSC, represented by UMAF F0927 and F0928, can induce MMD (Table 1).

Our results parallel those reported in a survey of MMD in Mexico (Otero-Colina et al. 2010), where five phylogenetically distinct Fusarium spp. within the American clade of the FFSC were associated with MMD (i.e., F. tupiense, F. sterilihyphosum, F. mexicanum, and two undescribed species), together with the African clade species F. pseudocircinatum. We were able to identify two of the three MMD pathogens in Spain based on the strong MP- and ML-BS support for their genealogical exclusivity with an ex-type strain (i.e., F. tupiense CML 262) or a reference isolate (i.e., F. mangiferae NRRL 26226) (O'Donnell et al. 1998a). Additional collections of the putatively novel MMD pathogen from Velez-Málaga, Spain (i.e., Fusarium sp. UMAF F0927 and F0928) are needed to critically assess its species status employing genealogical concordance phylogenetic species recognition (GCPSR) (Taylor et al. 2000). The following preliminary data, however, support our working hypothesis that multilocus molecular phylogenetic analyses of the species are likely to fulfill the rigorous requirements of GCPSR: (i) isolate UMAF F0927 is phylogenetically divergent from its nearest relatives (Fig. 6); (ii) BLASTn searches of NCBI GenBank, using the partial TEF1 and histone H3 sequences of UMAF F0927 Fusarium sp. as the queries, returned top matches that only showed $97 \%$ identity to $F$. udum, F. phyllophilum, and $F$. xylarioides (this percent identity is well below the threshold for conspecifics; http://www.cbs.knaw. nl/fusarium/); and (iii) morphological analysis of UMAF F0927 showed that it differed from the three aforementioned species in the production of polyphialides and sporodochial conidia and arrangement of conidia in short false chains on SNA, and it did not produce c-shaped curved conidia and chlamydospores. Failure to identify the sister of UMAF F0927 Fusarium sp. and to obtain a fully resolved phylogeny for the FFSC, in spite of assembling a $9.1-\mathrm{kb}$ seven-locus dataset that contained 1,129 parsimony informative characteristics, highlights the urgent need for additional phylogenetically informative genes in this clade and throughout this agronomically important, species-rich genus (Kvas et al. 2008).

Lima et al. (2009a) evaluated VCG diversity in F. tupiense from Brazil and identified six VCG, each of which possessed a unique AFLP banding pattern. All of the Spanish F. tupiense isolates tested $(n=92)$ were placed within VCG I together with $F$. tupiense isolate NRRL53995 from Brazil. With the exception of UMAF F1182, these isolates shared an identical ap-PCR profile. These results suggested that the $F$. tupiense population in Spain is genetically homogeneous and comprises a mostly clonal population, with all isolates belonging to the VCG I previously described in Brazil by Lima et al. (2009a); in contrast, however, with the high diversity founded by Lima et al. (2009a, 2012) for $F$. tupiense Brazilian populations.

In our study, we also observed genetic diversity in the ap-PCR and RAPD banding patterns among the Brazilian isolates, consistent with a previous report by Lima et al. (2009a). However, two different VCG (VCG III NRRL 53993 and VCG IV NRRL 53994) shared an identical ap-PCR and RAPD profile (Table 1; Fig. 4). Similar results were obtained in previous studies comparing VCG and AFLP analysis with $F$. oxysporum and $F$. pseudocircinatum from Acacia, where isolates of different VCG were grouped in the same AFLP cluster (Shiraishi et al. 2012). Although, F. tupiense isolates NRRL53984 (ex-holotype) and NRRL53995 were previously reported to share the same AFLP I banding pattern (Lima et al. 2009a), they were found to have distinct ap-PCR patterns in this study; they were almost identical for major bands but differ in the absence (in most of the cases) or presence of some minor bands (genotypes 6 and 1, respectively).

These results suggest that several molecular and genetic techniques, including VCG, ap-PCR, and multilocus or whole-genome sequencing, may need to be used in conjunction to fully characterize MMD genetic diversity. Additionally, in some cases, VCG analyses appear to be more discriminatory than ap-PCR, given that isolates in VCG III and IV showed identical banding patterns, as previously reported for $F$. mangiferae (Crespo et al. 2014). Zheng and Ploetz (2002) also found VCG analyses more discriminatory than RAPD technique for some of the Fusarium spp. isolates causing MMD.

The limited variability detected in the F. tupiense isolates in Spain is likely due to a recent introduction of the species into the country and suggests that $F$. tupiense may reproduce mostly asexually in Spain. In contrast to the low variability detected in the $F$. tupiense Spanish isolates, high genetic variation was observed by Lima et al. (2009a) in F. tupiense isolates from Brazil. This high variability was mainly due to the presence of both sexual and asexual reproduction among the Brazilian isolates, because sexual recombination increases the genetic pool (Lima et al. 2012). However, the fact that strains representing both MAT1-1 and MAT1-2 idiomorphs were identified among the $F$. tupiense isolates, even though only one MAT1-1 isolate was detected, suggests that this exotic pathogen may be able to reproduce sexually in Spain. This finding also raises the possibility that the mating types may have been independently introduced into Spain from different sources.

Results of the present study extend our knowledge of diagnostic morphological features of $F$. tupiense. The morphological markers available for distinguishing $F$. tupiense from other mango pathogens are limited (Lima et al. 2012). Although sterile, coiled hypha have been described for $F$. tupiense (Lima et al. 2012), none was found in the Spanish isolates of this species, indicating that this characteristic is not fixed. F. tupiense can be distinguished from the other MMD pathogens by the production of dendroid densely branched aerial conidiophores under black light (Fig. 2F to $\mathrm{H}$ ) when cultured on SNA. This diagnostic feature was not reported in the formal description (Lima et al. 2012). Similar dendroid aerial conidiophores have also been observed in four other species within the FFSC (F. circinatum, $F$. guttiforme, $F$. sterilihyphosum, and $F$. mangiferae) (Leslie and Summerell 2006; Nirenberg and O'Donnell 1998) but they were produced in the darkness without black-light illumination. F. mexicanum also causes MMD but it does not form dendroid aerial conidiophores on SNA (Otero-Colina et al. 2010).

The available data suggest that $F$. tupiense is spread by grafting infected nursery stock, as found on a small scale in nurseries (Ploetz and Freeman 2009). Thus, dissemination across large distances likely occurs via movement of propagation material (Lima et al. 2009a).

Although the origin of F. tupiense in Spain is unknown, our working hypothesis is that it was likely introduced on asymptomatic plant cuttings or seedlings from Brazil (Lima et al. 2009a) or Senegal (Senghor et al. 2012). Genetic analysis of F. tupiense from Senegal may help identify the origin of the MMD pathogens in Spain and elucidate the global epidemiology of this species. Although the putative novel MMD-causing UMAF F0927 Fusarium spp. could have also been introduced through asymptomatic plant cuttings or seedlings, 
possibly from Africa, given its placement within the African clade of the FFSC, it is also possible that it spread onto mango from a native host. As previously noted (Lima et al. 2009a), the mango malformation pathosystem might provide an excellent model for studying host adaptation because the disease occurs in different parts of the world where the MMD pathogens might be locally adapted.

Results of the present study add to a growing number of reports of multiple MMD pathogens in the same country, including Egypt (Haggag and El-Wahab 2009; Youssef et al. 2007) (e.g., F. mangiferae, $F$. sterilihyphosum, and $F$. proliferatum), Mexico (Freeman et al. 2014b; Otero-Colina et al. 2010) (F. mexicanum, F. pseudocircinatum, and a novel Fusarium sp.), and Malaysia (Mohamed Nor et al. 2013; Zheng and Ploetz 2002) ( $F$. proliferatum, $F$. mangiferae, and $F$. subglutinans). To explain this, our working hypothesis is that multiple independent introductions of MMD pathogens account for the species diversity in the Axarquía region, and it suggests that phytosanitary measures should be taken to prevent the introduction of novel pathogens and to minimize the spread of fusaria that are already established in Spain.

\section{Acknowledgments}

This research was supported by grants from CICE-Junta de Andalucía, Proyecto de Excelencia P07-AGR-02471 and P12-AGR-1473, co-funded by FEDER funds (EU). This work was also financed by a grant from SAT-2803 TROPS, Reyes Gutiérrez S. L. and Viveros Brokaw S. L. We thank J. M. Hermoso, E. Guirado, J. González (IHSM La Mayora-UMA-CSIC), and D. Sarmiento, (SAT-2803 TROPS) for their contributions to the pathogen survey. M. Crespo was also supported by a grant from the University of Málaga for a short stay in the Volcani Center, Bet Dagan, Israel.

\section{Literature Cited}

Aoki, T., O’Donnell, K., Homma, Y., and Lattanzi, A. R. 2003. Sudden death syndrome of soybean is caused by two morphologically and phylogenetically distinct species within the Fusarium solani species complex- $F$. virguliforme in North America and F. tucumaniae in South America. Mycologia 95:660-684.

Britz, H., Steenkamp, E. T., and Coutinho, T. A. 2002. Two new species of Fusarium section Liseola associated with mango malformation. Mycologia 94:722-730.

Butler, E. E., and Mann, M. P. 1959. Use of cellophane tape for mounting and photographing phytopathogenic fungi. Phytopathology 49:231-232.

Castellani, A. 1939. The viability of some pathogenic fungi in sterile distilled water. J. Trop. Med. Hyg. 42:225-226.

Correll, J. C., Klittich, C. J. R., and Leslie, J. F. 1987. Nitrate nonutilizing mutants of Fusarium oxysporum and their use in vegetative compatibility tests. Phytopathology 77:1640-1646.

Crespo, M., Arrebola, E., Cazorla, F. M., Maymon, M., Freeman, S., Torés, J. A., and de Vicente, A. 2014. Characterization of Fusarium mangiferae isolates from mango malformation disease in South of Spain. Eur. J. Plant Pathol. 139:247-253.

Crespo, M., Cazorla, F. M., Hermoso, J. M., Guirado, E., Maymon, M., Torés, J. A., Freeman, S., and de Vicente, A. 2012. First report of mango malformation disease caused by Fusarium mangiferae in Spain. Plant Dis. 96:286-287.

Freeman, S., Maymon, M., Biton, A., Levin, A. G., and Shtienberg, D. 2014a. Management of mango malformation disease based on a novel strategy of timing of fungicide applications combined with sanitation. Crop Prot. 61:84-91.

Freeman, S., Maymon, M., and Pinkas, Y. 1999. Use of GUS transformants of Fusarium subglutinans for determining etiology of mango malformation disease. Phytopathology 89:456-461.

Freeman, S., Otero-Colina, G., Rodríguez-Alvarado, G., Fernández-Pavía, S., Maymon, M., Ploetz, R. C., Aoki, T., and O'Donnell, K. 2014b. First report of mango malformation disease caused by Fusarium pseudocircinatum in Mexico. Plant Dis. 98:1583.

Freeman, S., Shtienberg, D., Maymon, M., Levin, A. G., and Ploetz, R. C. 2014c. New insights into mango malformation disease epidemiology lead to a new integrated management strategy for subtropical environments. Plant Dis. 98: 1456-1466.

Geiser, D. M., Ivey, M. L. L., Hakiza, G., Juba, J. H., and Miller, S. A. 2005. Gibberella xylarioides (anamorph: Fusarium xylarioides), a causative agent of coffee wilt disease in Africa, is a previously unrecognized member of the G. fujikuroi species complex. Mycologia 97:191-201.

Gerlach, W., and Nirenberg, H. 1982. The genus Fusarium-A pictorial atlas. Mitt. Biol. Bundesanst. Land Forstwirtsch. 209:1-40.

Haggag, W. M., and El-Wahab, A. 2009. First report of Fusarium sterilihyphosum and Fusarium proliferatum induced malformation disease of mango in Egypt. J. Plant Pathol. 91:231-240.

Iqbal, Z., Dasti, A. A., and Saleem, A. 2005. Selective growth media to study morphological and cultural characteristics of Fusarium mangiferae, the cause of mango malformation. In: Proc. First Int. Conf. Mango Date Palm: Culture and Export. A. U. Malik, M. A. Pervaiz, and K. Ziaf, eds. University of Agriculture, Faisalabad, Punjab, Pakistan

Kerényi, Z., Zeller, K. A., Hornok, L., and Leslie, J. F. 1999. Molecular standardization of mating type terminology in the Gibberella fujikuroi species complex. Appl. Environ. Microbiol. 65:4071-4076.

Klittich, C. J. R., and Leslie, J. F. 1988. Nitrate reduction mutants of Fusarium moniliforme (Gibberella fujikuroi). Genetics 118:417-423.

Kumar, J., Singh, U. S., and Beniwal, S. P. S. 1993. Mango malformation: One hundred years of research. Annu. Rev. Phytopathol. 31:217-232.

Kvas, M., Steenkamp, E. T., Al Adawi, A. O., Deadman, M. L., Al Jahwari, A. A., Marasas, W. F. O., Wingfield, B. D., Ploetz, R. C., and Wingfield, M. J. 2008. Fusarium mangiferae associated with mango malformation in the Sultanate of Oman. Eur. J. Plant Pathol. 121:195-199.

Leslie, J. F., and Summerell, B. A. 2006. The Fusarium Laboratory Manual. Blackwell Professional Publishing, Ames, IA.

Lima, C. S., Monteiro, J. H. A., Crespo, N. C., Costa, S. S., Leslie, J. F., and Pfenning, L. H. 2009a. VCG and AFLP analyses identify the same groups in the causal agents of mango malformation in Brazil. Eur. J. Plant Pathol. 123:17-26.

Lima, C. S., Pfenning, L. H., Costa, S. S., Abreu, L., and Leslie, J. F. 2012. Fusarium tupiense sp. nov., a member of the Gibberella fujikuroi species complex that causes mango malformation in Brazil. Mycologia 104:1408-1419.

Lima, C. S., Pfenning, L. H., Costa, S. S., Campos, M. A., and Leslie, J. F. 2009b. A new lineage within the Gibberella fujikuroi species complex is the main causal agent of mango malformation in Brazil. Plant Pathol. 58:33-42.

Marasas, W. F. O., Ploetz, R. C., Wingfield, M. J., Wingfield, B. D., and Steenkamp, E. T. 2006. Mango malformation disease and the associated Fusarium species. Symposium: Fusarium-induced diseases of tropical perennial crops. Phytopathology 96:667-672.

Mohamed Nor, K. M. I., Salleh, B., and Leslie, J. F. 2013. Fusarium species associated with mango malformation in Peninsular Malaysia. J. Phytopathol 161:617-624

Möller, E. M., Chelkowski, J., and Geiger, H. H. 1999. Species-specific PCR assays for the fungal pathogens Fusarium moniliforme and Fusarium subglutinans and their application to diagnose maize ear rot disease. J. Phytopathol. 147:497-508.

Nirenberg, H. I., and O'Donnell, K. 1998. New Fusarium species and combinations within the Gibberella fujikuroi species complex. Mycologia 90:434-458.

O’Donnell, K., Cigelnik, E., and Nirenberg, H. I. 1998a. Molecular systematics and phylogeography of the Gibberella fujikuroi species complex. Mycologia 90:465-493.

O’Donnell, K., Kistler, H. C., Cigelnik, E., and Ploetz, R. C. 1998b. Multiple evolutionary origins of the fungus causing Panama disease of banana: Concordant evidence from nuclear and mitochondrial gene genealogies. Proc. Natl. Acad. Sci. USA 95:2044-2049.

O’Donnell, K., Nirenberg, H. I., Aoki, T., and Cigelnik, E. 2000. A multigene phylogeny of the Gibberella fujikuroi species complex: Detection of additional phylogenetically distinct species. Mycoscience 41:61-78.

O’Donnell, K., Rooney, A. P., Proctor, R. H., Brown, D. W., McCormick, S. P., Ward, T. J., Frandsen, R. J. N., Lysoe, E., Rehner, S. A., Aoki, T., Robert, V. A. R. G., Crous, P. W., Groenewald, J. Z., Kang, S., and Geiser, D. M. 2013. Phylogenetic analyses of RPB1 and RPB2 support a middle Cretaceous origin for a clade comprising all agriculturally and medically important fusaria. Fungal Genet. Biol. 52:20-31.

Otero-Colina, G., Rodríguez-Alvarado, G., Fernández-Pavía, S., Maymon, M., Ploetz, R. C., Aoki, T., O'Donnell, K., and Freeman, S. 2010. Identification and characterization of a novel etiological agent of mango malformation disease in Mexico Fusarium mexicanum sp. nov. Phytopathology 100:1176-1184.

Ploetz, R. C. 2001. Malformation: A unique and important disease of mango, Mangifera indica L. Pages 233-247 in: Fusarium: Paul E. Nelson Memorial Symposium. American Phytopathological Society, St. Paul, MN.

Ploetz, R. C., and Freeman, S. 2009. Foliar, floral and soilborne diseases. Pages 231-302 in: The Mango, Botany, Production and Uses. R. Litz, ed. CABI Publishing, Wallingford, UK

Posada, D., and Crandall, K. A. 1998. MODELTEST: Testing the model of DNA substitution. Bioinformatics 14:817-818.

Rodríguez-Alvarado, G., Fernández-Pavía, S. P., Ploetz, R. C., and ValenzuelaVázquez, M. 2008. A Fusarium sp. different from Fusarium oxysporum and F. mangiferae is associated with mango malformation in Michoacán, Mexico. Plant Pathol. 57:781.

Senghor, A. L., Sharma, K., Kumar, P. L., and Bandyopadhyay, R. 2012. First report of mango malformation disease caused by Fusarium tupiense in Senegal. Plant Dis. 96:1582.

Shiraishi, A., Leslie, J. F., Zhong, S., and Uchida, J. Y. 2012. AFLP, pathogenicity, and VCG analyses of Fusarium oxysporum and Fusarium pseudocircinatum from Acacia koa. Plant Dis. 96:1111-1117.

Steenkamp, E. T., Wingfield, B. D., Coutinho, T. A., Zeller, K. A., Wingfield, M. J., Marasas, W. F. O., and Leslie, J. F. 2000. PCR-based identification of MAT-1 and MAT-2 in the Gibberella fujikuroi species complex. Appl. Environ. Microbiol. 66:4378-4382.

Swofford, D. L. 2003. PAUP*. Phylogenetic Analysis Using Parsimony (and other methods), version 4.0b10. Sinauer Associates, Sunderland, MA. 
Taylor, J. W., Jacobson, D. J., Kroken, S., Kasuga, T., Geiser, D. M., Hibbett, D. S., and Fisher, C. 2000. Phylogenetic species recognition and species concepts in fungi. Fungal Genet. Biol. 31:21-32.

Youssef, S. A., Maymon, M., Zveibil, A., Klein-Gueta, D., Sztejnberg, A., Shalaby, A. A., and Freeman, S. 2007. Epidemiological aspects of mango malformation disease caused by Fusarium mangiferae and source of infection in seedlings cultivated in orchards in Egypt. Plant Pathol. 56: 257-263.
Zhan, R.-L., Yang, S.-J., Ho, H.-H., Liu, F., Zhao, Y.-L., Chang, J.-M., and He, Y.-B. 2010. Mango malformation disease in south China caused by Fusarium proliferatum. J. Phytopathol. 158:721-725.

Zheng, Q., and Ploetz, R. C. 2002. Genetic diversity in the mango malformation pathogen and development of a PCR assay. Plant Pathol. 51:208-216.

Zwickl, D. J. 2006. Genetic algorithm approaches for the phylogenetic analysis of large biological sequence data sets under the maximum likelihood criterion Ph.D. dissertation, The University of Texas, Austin. 